\title{
Publication Activity of Russian Researches in Leading International Scientific Journals
}

\author{
M. N. Kotsemir \\ National Research University Higher School of Economics, Institute for Statistical Studies and \\ Economics of Knowledge, ul. Miasnitskaia, Moscow, 101000, Russia \\ E-mail: mkotsemir@hse.ru \\ Received 12.04.2012
}

\begin{abstract}
The primary aim of this research report is to analyse the dynamics and structure of the publications of Russian authors, as well as to define the place of Russian science in the global scientific process. Bibliometric analysis methods are the main methods for quantitative analysis of scientific cooperation, efficiency, and other aspects of scientific activity. The information base for this research includes materials from science citation databases containing bibliographic descriptions of the articles published in scientific journals (mainly written in English) in a significant number of fields of science. Various parameters (e.g. dynamics of the number of publications, the number of citation, the level of co-authorship, the scientific specialization index, etc.) at various levels of aggregation (e.g. individual researchers, research organizations, countries and regions of the world) can be calculated based on these data. The results of bibliometric studies can be used in a number of ways:

- analysis of latest trends in the development of various scientific fields;

- evaluation of the effectiveness of research organizations;

- overall assessment of the scientific potential of Russia (its strengths and weaknesses);

- identification the most productive scientists in various fields of science;

- drawing the international comparisons of publications;

- analysis of collaboration networks of scientific teams.
\end{abstract}

The paper analyses the basic indicators of the publication activity of scientists in Russia and the leading countries over the period between 2001 and 2011. Publication activity of Russian scientists is analysed in the context of specific areas of science. This allows the identification of areas of specialization of Russian publications. The paper also examines the dynamics of highly-cited publications and the indicators of the international scientific collaboration of Russian researchers. In this paper, materials of Web of Science database were used for analysis of publication activity.

KEYWORDS publication activity; bibliometric indicators; publications of Russian authors; the level of citation; cross-country analysis.

\section{INTRODUCTION}

The international and national science citation indices contained in the bibliographic descriptions of articles and reference lists are used in bibliometric analysis. Evaluation of the publication activity in Russian statistics practice began fairly recently [1-5]. Despite its rapid development, the Russian science citation index (RSCI) still fails to reflect the publication activity of Russian scientists adequately. Against this background, the materials of the science citation databases Web of Science (WoS) and the electronic analytical database Essential Science Indicators based on Web of Science were chosen as the infor- mation base for this work. Eugene Garfield established web of Science (WoS) in 1964. Web of Science is the first science citation database in the world owned by the Thompson Reuters information corporation. As of 2011, the Web of Science comprises approximately 48 million entries of scientific publications in over 15 thousand scientific journals. The database includes material presented in more than 148 thousand scientific conferences. The database includes science publications dating back to 1900 .

The Essential Science Indicators (ESI) in cross-country terms contains data on three basic publication activity indicators (the number of publications ("papers" column in ESI database); the number of citations received by these publications ("citations" column in ESI database), and the average number of citations per paper ("Citations per paper" column in ESI database) for 144 countries over the past 10 years. In turn, this ten-year period is divided into five-year sub-periods (at the time of writing, the data for 2001-2005, 2002-2006, 2003-2007, 2004-2008, 2005-2009, 2006-2010, and 2007-2011 were available in ESI database). Total number of publication was grouped into the 22 fields of science (according to the classification of the Essential Science Indicators). 
Table 1. Language structure of Russian papers: 2001-2011 (\%)

\begin{tabular}{|l|c|c|c|c|c|c|c|c|c|c|c|}
\hline \multicolumn{1}{|c|}{ Language } & 2001 & 2002 & 2003 & 2004 & 2005 & 2006 & 2007 & 2008 & 2009 & 2010 & 2011 \\
\hline English & 94.1 & 91.3 & 93.0 & 93.0 & 93.9 & 94.2 & 94.0 & 95.0 & 94.7 & 94.4 & 94.8 \\
\hline Russian & 4.6 & 6.3 & 4.5 & 5.0 & 4.1 & 3.8 & 4.4 & 3.5 & 3.1 & 1.9 & 3.9 \\
\hline Other languages & 1.3 & 2.5 & 2.5 & 2.0 & 2.0 & 2.0 & 1.6 & 1.5 & 2.2 & 3.7 & 1.3 \\
\hline
\end{tabular}

Notes: 1. The language structure of Russian papers was calculated as the dynamics of the share of Russian papers written in languages specified in the table (English, Russian, other languages) in the total number of publications by Russian authors for each year specified in the table.

2. In order to obtain the primary data from the Web of Science database, the option "Analyze results" was used (for the selected country "Russia" and the selected time period "2001-2011"); the initial data were then loaded from the category "Languages." The following types of documents were selected for the analysis: article, proceedings paper, and review.

Source: author calculations on Web of Science database materials. All databases of the Web of Science portal were used.

Studied sample includes countries with more than 10000 publications in ESI database for the years $2001-2011$. This sample consists of 57 countries. In certain cases, all the countries of the world will be under analysis.

A publication is affiliated to a certain country (Russia for example) if its author (or at least one of the co-authors) specified this country (Russia) in his or her working address. The terms "publications by Russian authors", "Russian publications", "publications of Russia" are used as synonyms. The following types of documents are classified under the term "publication": "article", "proceedings paper", and "review".

When performing a cross-country analysis of publication activity, one should take into account the fact that English-language publications currently dominate the science citation databases. Englishlanguage publications accounted for $94.8 \%$ of the total number of publications presented in the WoS database between 1990 and 2011 . At the same time publications in the French, German, Russian, Japanese, and Chinese languages accounted for only $1.2,1.1,0.6,0.22$, and $0.1 \%$, respectively. Moreover, the profiles of the publication activity in such fields of science as mathematics, computer science, natural science, and engineering are not sufficiently complete in these databases with area of social sciences and the humanities being the least complete. These limitations should be taken into account when interpreting bibliometric data.

\section{GLOBAL TRENDS IN PUBLICATION ACTIVITY}

The basic indicator of publication activity is the number of publications in peer-reviewed scientific journals. When comparing the publication activities of different countries, the share of publications attributed to the countries in the total world number of publications result in the countries rank in the global ranking of the number of publications. As mentioned, the international citation databases contain a relatively small number of nonEnglish-language publications. Consequently, the analysis of the publications of non-English-speaking authors will focus primarily on their English-language papers, which actually constitute a relatively small share of the total number of pub- lications in these countries. For example, only $10 \%$ of all Russian publications are indexed in the Web of Science database [1]. Therefore, the indicators of publication activity are artificially underestimated for such countries as Russia, Japan, China, India, as well as for Southeast Asia, Latin America, and the Middle East countries.

Web of Science database integrates five science citation databases:

- Science Citation Index Expanded (SCI-EXPANDED);

- Social Sciences Citation Index (SSCI);

- Arts \& Humanities Citation Index (A\&HCI);

- Conference Proceedings Citation Index-Science (CPCI-S); and

- Conference Proceedings Citation Index-Social Science \& Humanities (CPCI-SSH).

Data from all the databases within the Web of Science database are used for all the calculations, tables, and figures in this paper.

Data on scientific publications can be presented in the WoS database in different ways using the option "Analyze results". Table 1 shows the language structure of publications by Russian authors in 
Table 2. Dynamics of Russian publications: 2001-2011

\begin{tabular}{|c|c|c|}
\hline Year & $\begin{array}{c}\text { Number of Russian } \\
\text { publications }\end{array}$ & $\begin{array}{c}\text { Shares of Russian publications in the total } \\
\text { world number of publications, \% }\end{array}$ \\
\hline 2001 & 28665 & 2.97 \\
\hline 2002 & 29612 & 3.00 \\
\hline 2003 & 28648 & 2.75 \\
\hline 2004 & 28835 & 2.64 \\
\hline 2005 & 28281 & 2.45 \\
\hline 2006 & 27462 & 2.24 \\
\hline 2007 & 28926 & 2.16 \\
\hline 2008 & 30673 & 2.16 \\
\hline 2009 & 30904 & 2.09 \\
\hline 2010 & 29224 & 2.06 \\
\hline 2011 & 28573 & 2.12 \\
\hline
\end{tabular}

Notes: The option "Analyze results" was used to obtain the primary data in the Web of Science portal (for the selected country "Russia"); the initial data were then loaded from the category "Publication years."The following types of documents were selected for the analysis: article, proceedings paper, and review.

Source: author calculations on Web of Science database materials. All databases of the Web of Science portal were used.

scientific journals indexed in the Web of Science. The overwhelming majority (93-95\%) of papers are English-language publications. Throughout the studied period, the share of Russian-language publications in the total number of Russian publications in scientific journals indexed in the Web of Science varies between 1.9 and $6.3 \%$.

In 2011, the number of Russian publications in WoS slightly decreased in comparison with 2001 (Table 2). The minimal number of Russian publications over the studied was reached in $2006(27,462$ publications), followed by slight growth. The share of Russian publications in the global number of publications has dropped from $2.97 \%$ in 2001 to $2.12 \%$ in 2011.

Over the past decade, the U.S. led the absolute world leader on the number of publications in $\mathrm{WoS}(\mathrm{Ta}$ ble 3). Over the period of 2001-2011, Russia has lost six positions in this ranking, dropping from 9 th to 15 th place, overtaken by Spain, Australia, South Korea, Brazil, and the
Netherlands. The positions of Canada and Western European countries remained almost unchanged.

Iran showed the highest growth of number of publications among the studied countries: by a factor of 11.5 over 2001-2011 (Table 4). Malaysia, Pakistan, China, Saudi Arabia, Thailand, and Turkey also showed high increase (more than $200 \%$ over the studied period) in the number of number of publications in WoS. Among European countries, Portugal showed the highest increase in the number of publications (149\% over the 2011-2011). On the other hand some countries showed a decrease in the number of publications in scientific journals indexed in WoS in 2011 in comparison with 2001: Japan (by 7.4\%), Venezuela (by $8.2 \%$ ), and Belarus (by $15.9 \%$ ).

Countries with a rapidly increasing publication activity have improved their positions in the global ranking of the number of publications. Iran's position improved by 23 places (jump from the $42^{\text {nd }}$ place in
2001 to the $19^{\text {th }}$ place in 2011). Malaysia improved its position by 15 ranks (from the $45^{\text {th }}$ place in 2001 to the $34^{\text {th }}$ place in 2011). Some other countries (mainly from Asia and Latin America) also significantly improved their position in this ranking: Pakistan by 11 positions; Portugal by 9 positions; Turkey by 7 positions; Columbia by 6 positions; Saudi Arabia, Thailand, Brazil, and China by 4 positions each. In contrast, some countries (mainly from Eastern Europe) have lost many positions in the global ranking of number of publications. The following countries from the studied sample have lost six and more positions: Russia and Venezuela (6 positions), Hungary, Bulgaria and Slovakia (7 positions), Belarus (8 positions), and Ukraine (12 positions).

The dynamic growth of publication activity in developing countries led to a weakening of the dominance of the U.S. in the world science. In 2001, the share of the USA in the total world number of publications was $31.5 \%$; in 2011, it decreased to the level of $27.1 \%$. Meanwhile, the share of the second country in the rating increased from $8.9 \%$ in 2001 (in 2001, the second position was held by Japan) to $13.6 \%$ in 2011 (in 2011, the second position was held by China).

The data on the publication activity of different countries in the electronic analytical database Essential Science Indicators (ESI database) developed on Web of Science materials are presented in the "Countries/territories" subsection in the "Citation Rankings" section (option "View table of graph data").

The following indicators are provided for a specified country for five-year periods as well as for the whole period of 2001-2011 (option "View table of graph data"):

1) Number of papers;

2) Number of citations;

3) Average citations per paper. 
Table 3. Top 25 countries in the world rating for the number of publications

\begin{tabular}{|c|c|c|c|c|c|c|}
\hline \multirow[b]{2}{*}{ № } & \multicolumn{3}{|c|}{2001} & \multicolumn{3}{|c|}{2011} \\
\hline & Country & $\begin{array}{l}\text { Number } \\
\text { of publications } \\
\text { by the country }\end{array}$ & $\begin{array}{c}\text { Share } \\
\text { of the country } \\
\text { in the total world } \\
\text { number } \\
\text { of publications, \% }\end{array}$ & Country & $\begin{array}{l}\text { Number } \\
\text { of publications } \\
\text { by the country }\end{array}$ & $\begin{array}{c}\text { Share } \\
\text { of the country } \\
\text { in the total world } \\
\text { number } \\
\text { of publications, \% }\end{array}$ \\
\hline 1 & USA & 303917 & 31.48 & USA & 366507 & 27.13 \\
\hline 2 & Japan & 86096 & 8.92 & China & 184029 & 13.62 \\
\hline 3 & Great Britain & 83582 & 8.66 & Great Britain & 105411 & 7.80 \\
\hline 4 & Germany & 77982 & 8.08 & Germany & 97070 & 7.19 \\
\hline 5 & France & 55259 & 5.72 & Japan & 79751 & 5.90 \\
\hline 6 & China & 44575 & 4.62 & France & 67990 & 5.03 \\
\hline 7 & Canada & 38645 & 4.00 & Canada & 58855 & 4.36 \\
\hline 8 & Italy & 38453 & 3.98 & Italy & 55253 & 4.09 \\
\hline 9 & Russia & 28667 & 2.97 & Spain & 50256 & 3.72 \\
\hline 10 & Spain & 26350 & 2.73 & India & 46172 & 3.42 \\
\hline 11 & Australia & 25483 & 2.64 & South Korea & 45971 & 3.40 \\
\hline 12 & The Netherlands & 21779 & 2.26 & Australia & 44244 & 3.28 \\
\hline 13 & India & 19272 & 2.00 & Brazil & 34122 & 2.53 \\
\hline 14 & South Korea & 19194 & 1.99 & The Netherlands & 33523 & 2.48 \\
\hline 15 & Sweden & 17422 & 1.81 & Russia & 28577 & 2.12 \\
\hline 16 & Switzerland & 15566 & 1.61 & Taiwan & 28553 & 2.11 \\
\hline 17 & Brazil & 13324 & 1.38 & Switzerland & 24655 & 1.83 \\
\hline 18 & Taiwan & 13018 & 1.35 & Turkey & 23470 & 1.74 \\
\hline 19 & Poland & 12824 & 1.33 & Iran & 21768 & 1.61 \\
\hline 20 & Belgium & 11964 & 1.24 & Sweden & 21389 & 1.58 \\
\hline 21 & Israel & 10836 & 1.12 & Poland & 20818 & 1.54 \\
\hline 22 & Finland & 8822 & 0.91 & Belgium & 18686 & 1.38 \\
\hline 23 & Austria & 8779 & 0.91 & Denmark & 13468 & 1.00 \\
\hline 24 & Denmark & 8754 & 0.91 & Austria & 12852 & 0.95 \\
\hline 25 & Turkey & 7233 & 0.75 & Israel & 12493 & 0.93 \\
\hline
\end{tabular}

Notes: 1. In order to obtain the data on the total world number of publications in the Web of Science portal, the retrieval request "PY=2001 AND 2011" was input in the "Advanced search" insertion; the option "Analyze results" was then used to load the initial data from the category "Document types." The following types of documents were selected for analysis: article, proceedings paper, and review.

2. The option "Analyze results" was used to obtain the data on the number of publications in the countries studied on the Web of Science portal (for 2001 and 2011); the initial data were then loaded from the category "Countries/territories." The following types of documents were selected for analysis: article, proceedings paper, and review.

3. The sum of the shares for all countries is higher than $100 \%$, since some papers were prepared in international coauthorship.

Source: author calculations on Web of Science database materials. All databases of the Web of Science portal were used. 
Table 4. Country composition of the studied sample with the most dynamically increasing number of publications: 2001-2011

\begin{tabular}{|c|c|c|c|}
\hline \multirow{2}{*}{ Country } & \multicolumn{2}{|c|}{ Number of publications } & \multirow{2}{*}{$\begin{array}{c}\text { The number of publications } \\
\text { increased in } 2001-2011 \\
\text { by a factor of }\end{array}$} \\
\hline & 2001 & 2011 & \\
\hline Iran & 1891 & 21768 & 11.51 \\
\hline Malaysia & 1216 & 8713 & 7.17 \\
\hline China & 44575 & 184029 & 4.13 \\
\hline Pakistan & 739 & 5682 & 5.47 \\
\hline Saudi Arabia & 1451 & 5651 & 3.89 \\
\hline Thailand & 1727 & 5991 & 3.47 \\
\hline Turkey & 7233 & 23470 & 3.24 \\
\hline
\end{tabular}

Notes: In order to obtain the primary data from the Web of Science portal, the option "Analyze results" was used for the countries specified in the table; the initial data were then loaded from the category "publication years." The following types of documents were selected for the analysis: article, proceedings paper, and review.

Source: author calculations on Web of Science database materials. All databases of the Web of Science portal were used.

In essence, the latter indicator is the ratio between the second and the first indicators. All three indicators can be calculated both for each of the 22 fields of science specified by WoS and for the total number of publications ("All fields" category). The same indicators are available for the total world number of scientific papers. The data on global indicators of publication activity are presented in the "Baselines" subsection in the "Citation Analysis" section ("View field rankings table" option). Similar to the case of individual countries, the global indicators of publication activity can be calculated both for the 22 fields of science and for the total number of publications for the specified fiveyear periods and for the whole period of 2001-2011.

It should be noted here that the total number of publications of a certain country during a certain five-year period can be obtained via the summing up the numbers of publications (and citations) of all 22 fields of science. In other words, the subjects of 22 fields of science specified in the Essential Science Indicators do not overlap. Meanwhile, the global number of publications (and citations) obtained via the summing up of publications of all countries exceeds the real total world number of publications (and citations), due to the fact that some papers result from international collaboration. Subsequently, these publications are assigned to all the countries whose authors participated in these publications. Therefore, by summing up the number of publications (and citations of these publications) of all countries, some papers (and citations) will actually be accounted several times.

The thematic structure of Russian publications in WoS differs from the global one (Table 5). Physics is the most significant field of science in Russia. Publications on physics accounted for $28 \%$ of the total number of Russian publications in 2001-2011. The second and the third most significant fields of science are chemistry (22.2\%) and engineering (7.6\%).

Clinical medicine is the most significant field of science in the world structure of publications: its share in the total number of scientific publications was $21.0 \%$ in $2011-$ 2011. The second and the third most significant fields of study are chemistry $(12.0 \%)$ and physics (9.3\%). The share of Russian publications on clinical medicine, computer and social sciences in total world number of publications was very small. No significant changes in the thematic structure of Russian publications were observed during the studied period. Nevertheless, it should be noted that in the structure of Russian publications the share of publications on pharmacology \& toxicology, economics \& business, multidisciplinary studies, and environment/ecology considerably increased.

By comparing the thematic structure of scientific publications in a specific country with the same global structure, it is possible to calculate the index of scientific specialisation of the country [1]. This index is calculated as the ratio between the shares of publications in the field of studies $i$, within the total number of publications of country $j$, and the same indicator for the global structure of publications. If this index is greater than one in a certain discipline, thus this discipline belongs to the sphere of scientific specialization sphere of that particular country.

The main areas of scientific specialization of Russian science are physics, space science, and geosciences (Fig. 1). Significant areas of specialization include mathematics, chemistry, and materials science. Publications on pharmacol- 
Table 5. Distribution of publications over fields of science (\%)

\begin{tabular}{|c|c|c|c|c|}
\hline \multirow{2}{*}{ Field of science } & \multicolumn{2}{|c|}{ World structure } & \multicolumn{2}{|c|}{ Russian structure } \\
\hline & $2001-2005$ & $2007-2011$ & $2001-2005$ & $2007-2011$ \\
\hline Biology \& biochemistry & 6.08 & 5.17 & 4.01 & 3.48 \\
\hline Immunology & 1.33 & 1.14 & 0.16 & 0.20 \\
\hline Clinical medicine & 20.79 & 21.24 & 4.70 & 5.09 \\
\hline Computer science & 2.97 & 2.09 & 1.20 & 0.84 \\
\hline Mathematics & 2.47 & 2.81 & 4.42 & 5.46 \\
\hline Materials science & 4.60 & 4.70 & 6.25 & 6.01 \\
\hline Microbiology & 1.66 & 1.69 & 1.27 & 1.20 \\
\hline Molecular biology and genetics & 2.83 & 2.78 & 2.12 & 2.24 \\
\hline Multidisciplinary & 0.17 & 0.17 & 0.07 & 0.13 \\
\hline Geosciences & 2.83 & 2.92 & 7.11 & 8.08 \\
\hline Space science & 1.31 & 1.15 & 3.31 & 3.23 \\
\hline Plant \& animal science & 5.56 & 5.42 & 2.29 & 2.60 \\
\hline Environment/ecology & 2.57 & 2.88 & 0.90 & 1.50 \\
\hline Neuroscience \& behaviour & 3.16 & 2.85 & 0.78 & 0.78 \\
\hline Social science & 4.06 & 5.12 & 1.08 & 0.95 \\
\hline Psychiatry/psychology & 2.38 & 2.49 & 0.50 & 0.44 \\
\hline Agricultural science & 1.85 & 2.30 & 0.70 & 0.77 \\
\hline Engineering & 8.02 & 8.66 & 7.95 & 7.27 \\
\hline Pharmacology \& toxicology & 1.79 & 1.96 & 0.19 & 0.46 \\
\hline Physics & 9.71 & 8.98 & 28.29 & 27.34 \\
\hline Chemistry & 12.31 & 11.62 & 22.58 & 21.76 \\
\hline Economics \& business & 1.54 & 1.84 & 0.10 & 0.18 \\
\hline
\end{tabular}

Notes: The distribution of publications over fields of science was calculated as the dynamics of the shares of the publications in the specified fields of science in the total number of publications.

Source: author calculations on of Essential Science Indicators database materials (section "Citation Rankings, subsection "Countries/territories" country "Russia," option "View table of graph data" for Russian indicators ; section "Citation Analysis," subsection "Baselines," option "View field rankings table" for the total world indicators).

ogy and toxicology, economics and business, and multidisciplinary studies showed the most significant increase in the index of scientific specialization in 2007-2011 in comparison with 2001-2005 On the contrary, index of scientific specialization for publications on social sciences decreased dramatically.
Russian authors have contributed substantially to the total global number of scientific papers (Fig. 2) on physics $(7.9 \%$ of the total world number), space science ( $7.1 \%)$, and geosciences (6.7\%). Russian publications on chemistry, mathematics, and materials science were also significantly presented in the world science: they accounted to
$3-5 \%$ of the total world number in 2001-2011. As previously mentioned, Russia has lost positions in world science over the period of $2001-2011$. Let us analyse this phenomenon in the context of fields of science. In 2007-2011 in comparison with 2001-2005 Russian publications on social science, psychiatry \& psychology, materi- 


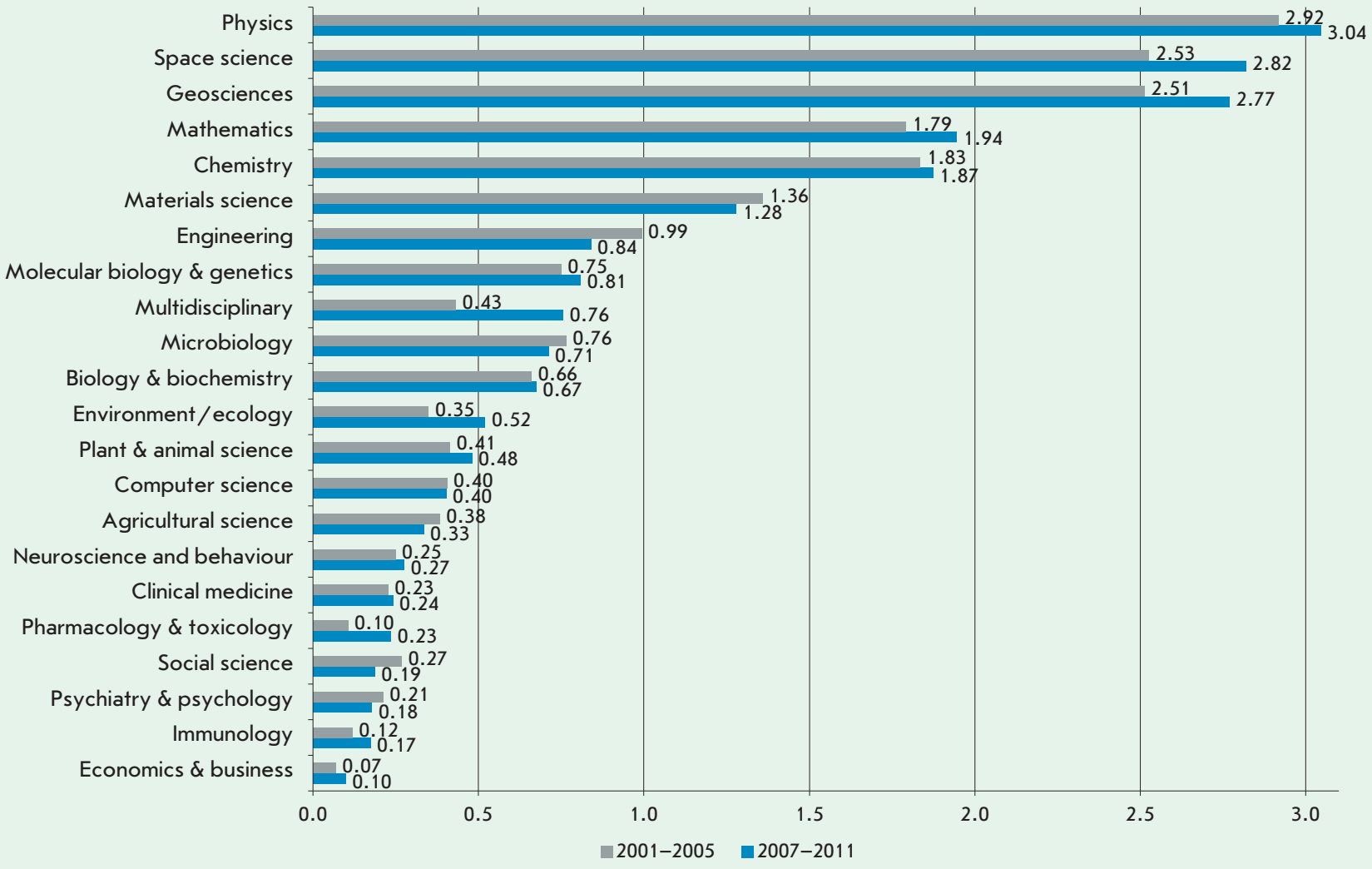

Fig. 1. Indices of the specialization of Russian publications in different fields of science.

Source: author calculations on Essential Science Indicators database materials (section "Citation Rankings, subsection "Countries/territories" country "Russia," option "View table of graph data" for indicators for Russia; section "Citation Analysis," subsection "Baselines," option "View field rankings table" for the total world indicators).

als science, and engineering have lost their positions in the world science more dramatically than publication s on other field of science. The share of Russian publications in the other areas of its scientific specialization has also decreased. Meanwhile, Russia has strengthened its position in the fields of multidisciplinary studies, as well as pharmacology \& toxicology, over the studied period.

\section{MAJOR TENDENCIES IN PUBLICATION CITATION}

Citation indices are used to evaluate the scientific impact of the publications of a certain researcher or a country in general. The average number of citations per publication is the basic indicator, which is de- termined as the ratio between the number of citations on the publications published by a specific country and the number of these publications in scientific journals reviewed by the science citation database over a certain period. This indicator is typically assessed for a certain period (usually, 3-5 years) rather than for one year. The reason can be explained as follows: some period is necessary before a publication included in the international citation database can accumulate a significant number of citations. Let us note that in the context of this work indicator "average number of citations per publication" refer three kinds of scientific documents: article, proceedings paper and review.
The following procedure is used in the Essential Science Indicators database to calculate the average number of citations per paper. There are two basic indicators:

- total number of publications ("Number of papers" indicator in ESI database) of a specific country published during the specified 5-year period (2001-2005 for example) in scientific journals, indexed by Web of Science ("Number of papers" indicator in ESI database);

- number of citations on this publications during this (2001-2005) 5 -year period ("Number of citations" indicator in ESI database).

Therefore, the average number of citations per paper (ACP further) indicator is simply the ration of $B$ and $\mathrm{A}$ indicators. Such an approach 


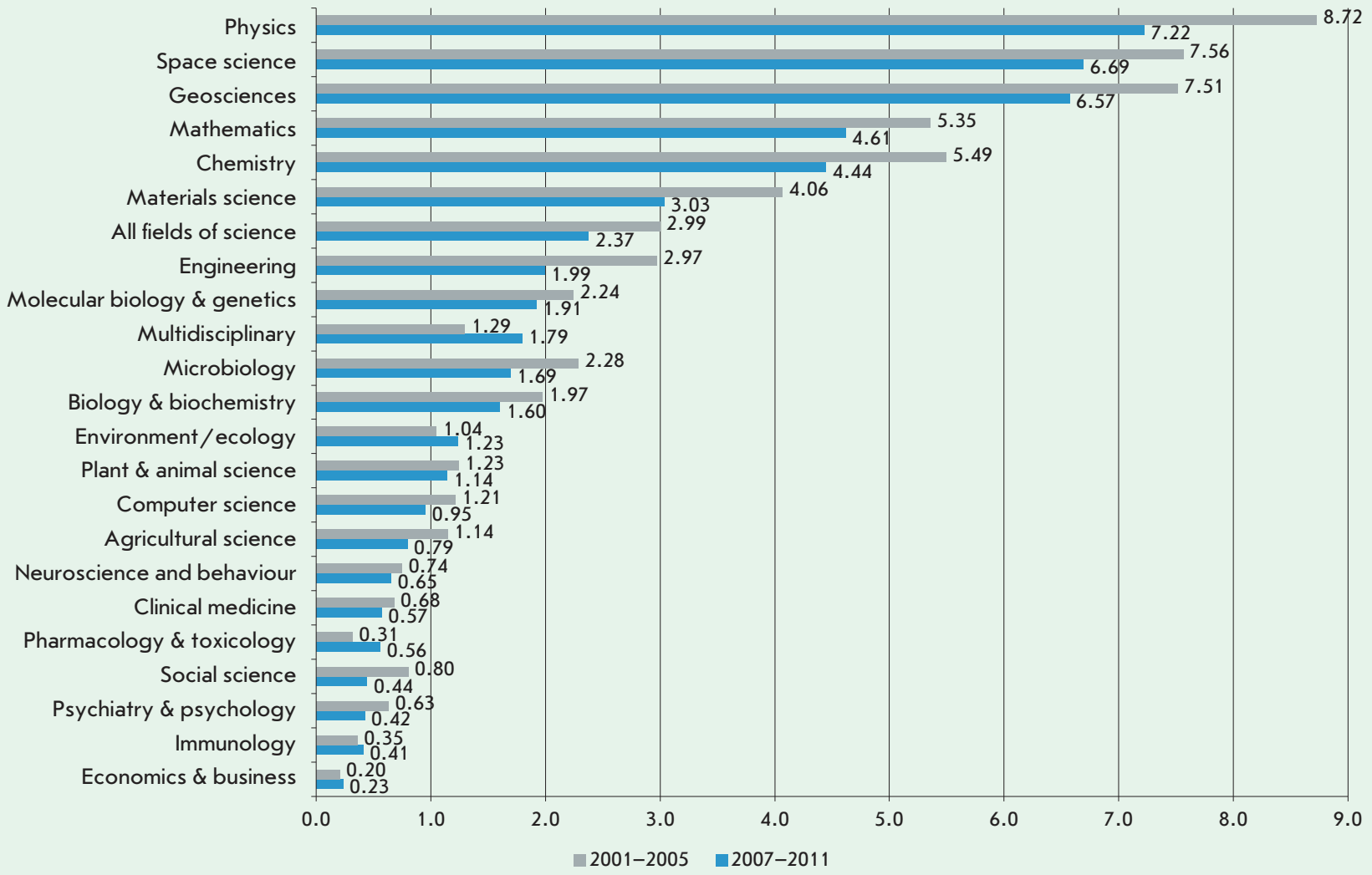

Fig. 2. Shares of Russian publications in the total world number of publications on fields of science (\%).

Source: author calculations on Essential Science Indicators database materials (section "Citation Rankings, subsection "Countries/territories" country "Russia," option "View table of graph data" for Russian indicators; section "Citation Analysis," subsection "Baselines," option "View field rankings table" for the total world indicators).

to calculation the ACP indicator allows cross-time evaluation of average level of citation of publications.

Analysis of citation indicator should be performed with caution. The number of citations does not always adequately represent the quality of publications, since opportunities to be citied are not equal for authors of different countries. So-called "Matthew effect that has been repeatedly observed in different fields of science [6-10] should be mentioned here. The Matthew effect was first mentioned in 1968 in the article of the American sociologist Robert Merton in Science $[6,7]$. The researcher analysed the psychosocial factors affecting the recognition and evaluation of scientific papers. The Matthew ef- fect means that scientific research carried out by famous authors is somehow superior to that made by their less outstanding colleagues. The effect was named in light of the flowing quote from the Gospel According to St. Matthew: "For unto every one that hath shall be given, and he shall have abundance: but from him that hath not shall be taken even that which he hath" (Matthew 25:29, King James Version). In context of countries Mathew effect means that publication from "prestigious" (e.g. from the USA) country has, other thing equal, (it is assumed that the article from the U.S. author and the article from Tajik author are devoted to the same problem, have the equal scientific level and are written in the same language with the same level of the grammatical correctness), more opportunities than the publication from "unprestigious" (e.g. from Tajikistan) country.

The countries with a small number of publications in the international science citation databases often have extremely high level of the ACP indicator. Let us use the following example to illustrate. The Bermuda Islands, Panama, and Gambia held the first three positions in the ranking of the ACP indicator level over the period of 2001-2011, respectively. The value of the ACP indicator in these countries was $23.7,17.9$, and 17.0 citations per paper, respectively. Gabon and Guinea-Bissau were also among the top 20 countries of this 
Table 6. The average number of citations per paper in the leading countries: 2001-2011

\begin{tabular}{|c|c|c|c|c|}
\hline № & Страна & $\begin{array}{l}\text { Average number of citations } \\
\text { per paper for the country }\end{array}$ & $\begin{array}{l}\text { Number of publications } \\
\text { of the country }\end{array}$ & $\begin{array}{l}\text { Position of the country in } \\
\text { the ranking of the number of } \\
\text { publications }\end{array}$ \\
\hline 1 & Switzerland & 16.61 & 194618 & 16 \\
\hline 2 & USA & 15.83 & 3219337 & 1 \\
\hline 3 & Denmark & 15.83 & 104212 & 23 \\
\hline 4 & The Netherlands & 15.53 & 268385 & 14 \\
\hline 5 & Sweden & 14.82 & 189413 & 18 \\
\hline 6 & Great Britain & 14.79 & 912495 & 2 \\
\hline 7 & Belgium & 13.69 & 147261 & 21 \\
\hline 8 & Finland & 13.59 & 94209 & 25 \\
\hline 9 & Germany & 13.20 & 836694 & 4 \\
\hline 10 & Canada & 13.15 & 479354 & 7 \\
\hline 11 & Austria & 12.92 & 102129 & 24 \\
\hline 12 & Israel & 12.72 & 117251 & 22 \\
\hline 13 & Norway & 12.56 & 77118 & 29 \\
\hline 14 & France & 12.32 & 598138 & 6 \\
\hline 15 & Australia & 11.97 & 323344 & 10 \\
\hline 16 & Italy & 11.81 & 458871 & 8 \\
\hline 17 & Ireland & 11.51 & 49358 & 37 \\
\hline 18 & New Zealand & 10.84 & 61205 & 34 \\
\hline 19 & Spain & 10.42 & 364197 & 9 \\
\hline 20 & Japan & 10.35 & 815789 & 5 \\
\hline
\end{tabular}

Notes: 1 . The top 20 countries from the studied sample in terms of the average number of citations per paper are considered.

2. All indicators were calculated for the total number of publications over the period of 2001-2011 in scientific journals indexed in the Web of Science.

3. The average number of citations per paper is determined as the ratio between the number of citations received in 2001-2011 by the publications of the country published in 2001-2011 to the number of these publications.

Source: author calculations on Essential Science Indicators database materials (section "Citation Rankings, subsection "Countries/territories," option "View table of graph data" for indicators of the countries listed in the table; section "Citation Analysis," subsection "Baselines," option "View field rankings table" for the total world indicators).

ranking. However, in all these countries with the exception of Panama, the total number of publications in scientific journals indexed by WoS over the period of 2001-2011 was below 1,000 (in Panama, the number of papers was 2,098).

According to ESI data, Russia held the 123rd position (out of 144) in the world rating on the ACP indicator level. The average number of citations received by a Russian paper published over the period of 2001-2011 was relatively low: 4.87, much lower than the global average of 10.57 citations per paper. Despite this, Russia held the relatively high position of $21^{\text {st }}$ in the ranking of the absolute number of citations received by papers.

Table 6 lists the first 20 countries for the level of the ACP indicator within the studied sample. Englishspeaking countries and Northern European countries hold the first 12 positions in this ranking, whereas Russia holds the $47^{\text {th }}$ position out of 57 countries.
The value of the ACP indicator in all countries characterized with rapidly growing publication activity was lower compared to the global level. Among these countries, Thailand stood had the highest value of the ACP indicator: 7.57 citations per paper (the $72^{\text {nd }}$ position in the world). The other countries characterized by a rapid increase in the number of scientific papers in the leading world journals held positions below the top 100 in the global 
Table 7. Top 25 countries of the world ranking of the number of citations of publications

\begin{tabular}{|c|c|c|c|c|c|c|}
\hline \multirow[b]{2}{*}{ № } & \multicolumn{3}{|c|}{$2001-2005$} & \multicolumn{3}{|c|}{$2007-2011$} \\
\hline & Country & $\begin{array}{l}\text { Number of } \\
\text { citations of the } \\
\text { publications of } \\
\text { the country }\end{array}$ & $\begin{array}{l}\text { Share of the } \\
\text { country in the } \\
\text { total world } \\
\text { number of publi- } \\
\text { cation citations, \% }\end{array}$ & Страна & $\begin{array}{l}\text { Number of } \\
\text { citations of the } \\
\text { publications of } \\
\text { the country }\end{array}$ & $\begin{array}{l}\text { Share of the } \\
\text { country in the } \\
\text { total world } \\
\text { number of publi- } \\
\text { cation citations, \% }\end{array}$ \\
\hline 1 & USA & 8736259 & 47.5 & USA & 11542290 & 42.2 \\
\hline 2 & Great Britain & 2231223 & 12.1 & Great Britain & 3330285 & 12.2 \\
\hline 3 & Germany & 1900402 & 10.3 & Germany & 2788268 & 10.2 \\
\hline 4 & Japan & 1576262 & 8.6 & China & 2219953 & 8.1 \\
\hline 5 & France & 1244048 & 6.8 & France & 1852765 & 6.8 \\
\hline 6 & Canada & 971332 & 5.3 & Japan & 1840922 & 6.7 \\
\hline 7 & Italy & 870611 & 4.7 & Canada & 1641349 & 6.0 \\
\hline 8 & The Netherlands & 650939 & 3.5 & Italy & 1462765 & 5.3 \\
\hline 9 & Australia & 572221 & 3.1 & Spain & 1111348 & 4.1 \\
\hline 10 & China & 569874 & 3.1 & The Netherlands & 1086107 & 4.0 \\
\hline 11 & Spain & 549353 & 3.0 & Australia & 1071029 & 3.9 \\
\hline 12 & Switzerland & 529890 & 2.9 & Switzerland & 857170 & 3.1 \\
\hline 13 & Sweden & 471150 & 2.6 & South Korea & 677451 & 2.5 \\
\hline 14 & Belgium & 308583 & 1.7 & Sweden & 666464 & 2.4 \\
\hline 15 & South Korea & 288106 & 1.6 & India & 587965 & 2.1 \\
\hline 16 & Denmark & 265646 & 1.4 & Belgium & 551464 & 2.0 \\
\hline 17 & Israel & 262033 & 1.4 & Brazil & 436681 & 1.6 \\
\hline 18 & Russia & 258172 & 1.4 & Denmark & 426175 & 1.6 \\
\hline 19 & India & 225529 & 1.2 & Taiwan & 413885 & 1.5 \\
\hline 20 & Finland & 217603 & 1.2 & Austria & 347819 & 1.3 \\
\hline 21 & Austria & 215013 & 1.2 & Israel & 338029 & 1.2 \\
\hline 22 & Brazil & 185243 & 1.0 & Russia & 317770 & 1.2 \\
\hline 23 & Poland & 178917 & 1.0 & Finland & 309117 & 1.1 \\
\hline 24 & Taiwan & 173626 & 0.9 & Poland & 302810 & 1.1 \\
\hline 25 & Norway & 140394 & 0.8 & Turkey & 267440 & 1.0 \\
\hline
\end{tabular}

Notes: 1. The indicator "number of citations per publications of the country" is the number of citations received over the period of 2001-2005 (and 2007-2011) by the publications of the country in 2001-2005 (and 2007-2011).

2. The total world number of citations received by the publications is calculated for the actual number of the scientific publications of all the countries present in the Essential Science Indicators (section "Citation Analysis," subsection "Baselines," option "View field rankings table").

Source: author calculations on Essential Science Indicators database materials (section "Citation Rankings, subsection "Countries/territories," option "View table of graph data" for indicators for the countries listed in the table; section "Citation Analysis," subsection "Baselines," option "View field rankings table" for the total world indicators).

ranking of the value of the $\mathrm{ACP}$ indicator. Iran, the country with the most dynamic increase in the absolute number of papers among the countries of the studied sample, had one of the lowest indi- cators of the average number of citations per paper in the world - 4.19 citations per paper $\left(133^{\text {rd }}\right.$ position in the world rating). The value of the ACP indicator in European countries was higher than in Asian countries. Japan had the highest average number of citations per paper among Asian countries: 10.35 citations per paper and he $35^{\text {th }}$ position in the world rating for this indicator). 
Among the BRIC countries, Brazil had the maximum level of the ACP indicator: 6.37 citations per paper $\left(100^{\text {th }}\right.$ position in the global ranking). In China and India, the average number of citations per paper was also higher than in Russia: $103^{\text {rd }}$ and $108^{\text {th }}$ positions in the world, respectively (6.15 and 5.87). Estonia stands out among the countries of the former Soviet Union for the highest value of the ACP indicator: 9.35 citations per paper $\left(45^{\text {th }}\right.$ position in the world). In all Baltic countries, the average number of citations per paper was higher than in Russia. On the contrary, the average number of citations per paper in Central Asian countries, as well as in Belarus and Ukraine, was lower than that in Russia. Azerbaijan had the lowest value of the ACP indicator among the former USSR countries: 2.71 citations per paper, $143^{\text {rd }}$ position in the global ranking. Serbia held the lowest $144^{\text {th }}$ position in the world rating on the value of the ACP indicator with 2.66 citations per paper.

As mentioned previously, the analytical database Essential Science Indicators enables one to dynamically compare the average number of citations per paper and the absolute number of citations received by publications. Among the countries of studied sample, the most significant growth (by more than 50\%) in the average number of citations per paper was shown by such countries as Singapore (89.7\%), Tunisia $(68.5 \%)$, Iran (61.6\%), China (60.4\%), Egypt (57.9\%), Algeria (57.4), Greece (55.8\%) and Turkey (50.3\%).

The U.S. was the stable global leader on absolute number of citations received by publications over the studied period. The dominance of the U.S. over the other countries in terms of this indicator is even more pronounced than that in terms of the number of publications (Table 7). The papers published by U.S. authors during the period of
2001-2011 received $45.3 \%$ of the total world number of citations. This indicator fell slightly from $47.5 \%$ to $42.2 \%$ over the studied period. The shares of Great Britain and Germany, which held the second and third positions, respectively, in the ranking of the number of citations over the period of 2001-2011, remained almost unchanged over the specified period. Russia held the $22^{\text {nd }}$ position in this ranking. During the specified period, Russia lost by four positions dropping from $18^{\text {th }}$ to $22^{\text {nd }}$.

China, which held the second position in the ranking of number of publications, ranked $7^{\text {th }}$ in the ranking of the number of citations ( $5 \%$ of the total world number of citations). Over the period under analysis, China improved its rank by six positions: jumping from $10^{\text {th }}$ to $4^{\text {th }}$ place. In addition to China, some other countries with dynamic publication activity also improved their positions in this ranking: Iran (10 positions), Pakistan (8 positions), Malaysia (7 positions), China (6 positions), Brazil, Singapore, and Taiwan (5 positions each). Among the countries of the studied sample under more than threefold increase in the number of citations on publications issued over the period of 2001-2011 was observed in Iran (7.4 times), Pakistan (5.9 times), Malaysia (4.8 times), China (3.9 times), Algeria (3.7 times), Thailand (3.4 times), Nigeria (3.2 times), and Columbia (3.1 times). However, a dramatic increase in the absolute number of citations on publications did little to help these countries to score high citation indices.

The following countries lost positions in the ranking of the number of citations on publications: Russia, Estonia and Israel lost four positions each; New Zealand and Slovakia five positions each; Ukraine lost six positions, Hungary and Venezuela both lost eight positions. As in the case for the number of publications, the positions of the North European and North American countries in the ranking of the number of citations remained almost unchanged over the period of 2001-2011. Despite the loss of position in the ranking of the number of citations on publications, Hungary held the relatively high 38 th position in the rating for the level, in contract to Venezuela, which held the $84^{\text {th }}$ position. Israel, New Zealand, and Estonia also held relatively high positions $17^{\text {th }}, 28^{\text {th }}$ and $45^{\text {th }}$, respectively.

The distribution of citations on Russian publications over the fields of science for Russian papers, as well as the structure of papers, strongly differed from the world distribution (Table 8 ). $37.5 \%$ of all the citations over the period of 2001-2011 were received by Russian publications on physics. The share of the remaining fields of science in the total number of citations on publications by Russian authors was considerably lower. Nevertheless, the share of citations received by Russian publications on physics decreased in 2007-2011 as compared to that in 2001-2005. Meanwhile, the share of citations received by Russian publications on clinical medicine substantially increased from $3.8 \%$ to $7.8 \%$.

The field of clinical medicine was dominant in the world structure of citations, accounting for $25.2 \%$ of the total number of citations. Chemistry and physics held the second and third positions in terms of the number of citations received (12.1\% and $8 \%$ of the total number of citations, respectively). The share of citations received by the publications on biology \& biochemistry decreased most significantly in the world structure of science over the period of 2001-2011.

The shares of citations on Russian publications in the total world number of citations for different fields of science are presented in Fig. 3. Russian publications on physics and astronomy received 
Table 8. Distribution of the citations on publications over fields of science (\%)

\begin{tabular}{|c|c|c|c|c|}
\hline \multirow{2}{*}{ Field of science } & \multicolumn{2}{|c|}{ World structure } & \multicolumn{2}{|c|}{ Russian structure } \\
\hline & $2001-2005$ & $2007-2011$ & $2001-2005$ & $2007-2011$ \\
\hline Biology \& biochemistry & 10.47 & 7.63 & 6.66 & 5.54 \\
\hline Immunology & 2.98 & 2.29 & 0.36 & 0.59 \\
\hline Clinical medicine & 25.56 & 25.09 & 3.79 & 7.81 \\
\hline Computer science & 0.82 & 0.91 & 0.32 & 0.27 \\
\hline Mathematics & 0.68 & 0.94 & 1.36 & 1.86 \\
\hline Materials science & 2.46 & 3.75 & 3.26 & 3.78 \\
\hline Multidisciplinary & 0.07 & 0.12 & 0.01 & 0.20 \\
\hline Microbiology & 2.64 & 2.35 & 1.59 & 1.52 \\
\hline Molecular biology and genetics & 7.82 & 6.20 & 3.60 & 3.33 \\
\hline Geosciences & 2.19 & 2.58 & 4.93 & 6.48 \\
\hline Space science & 2.02 & 1.81 & 5.18 & 5.61 \\
\hline Plant \& animal science & 3.69 & 3.69 & 1.59 & 1.94 \\
\hline Environment/ecology & 2.16 & 2.98 & 0.96 & 1.42 \\
\hline Neuroscience \& behaviour & 5.68 & 4.79 & 1.33 & 1.17 \\
\hline Social science & 1.48 & 2.10 & 0.19 & 0.27 \\
\hline Psychiatry/psychology & 2.00 & 2.36 & 0.25 & 0.21 \\
\hline Agricultural science & 1.04 & 1.46 & 0.20 & 0.39 \\
\hline Engineering & 2.92 & 4.37 & 4.90 & 4.39 \\
\hline Pharmacology \& toxicology & 2.05 & 2.29 & 0.31 & 0.52 \\
\hline Physics & 8.60 & 7.67 & 43.49 & 35.49 \\
\hline Chemistry & 12.09 & 13.71 & 15.65 & 17.15 \\
\hline Economics \& business & 0.58 & 0.91 & 0.08 & 0.09 \\
\hline
\end{tabular}

Notes: The distribution of the publication citations over fields of science is calculated as the dynamics of the shares of citations for publications in the specified fields of science in the total number of citations on publications.

Source: author calculations on Essential Science Indicators database materials (section "Citation Rankings, subsection "Countries/territories" country "Russia," option "View table of graph data" for Russian indicators; section "Citation Analysis," subsection "Baselines," option "View field rankings table" for the total world indicators).

the largest share of the total world number of citations in comparison to the papers from other fields of science (the total being $6.1 \%$ over the period of 2001-2011). Russian publications on mathematics, geosciences, and space science received $2 \%-4 \%$ of the total world number of citations. The share of citations on Russian publications on physics and engineering in the total world number of such citations seriously decreased over the period of 2001-2011. On the other hand, this indicator for publications on multi- disciplinary studies increased considerably (from 0.3 to $1.9 \%$ ). Table 9 lists the values of the ACP indicator for Russian publications from different fields of science over the period of 2001-2011. Russian publications o immunology had the highest average number of citations per paper. However, the world level of the $\mathrm{ACP}$ indicator for publications on immunology was higher than the Russian one.

Russian publications on mathematics, social and computer sciences had the lowest value of the ACP indicator in comparison with publications from other fields of science over the period of 2001-2011. In 2001-2005, the value of the ACP indicator for Russian publications on economics \& business was comparable to the corresponding world indicator. However, the level of ACP indicator of Russian publications from these fields, as well as those from the field of pharmacology \& toxicology, decreased in 2007-2011 by $28 \%$ and $19 \%$, respectively.

Russian publications on multidisciplinary studies showed quick 


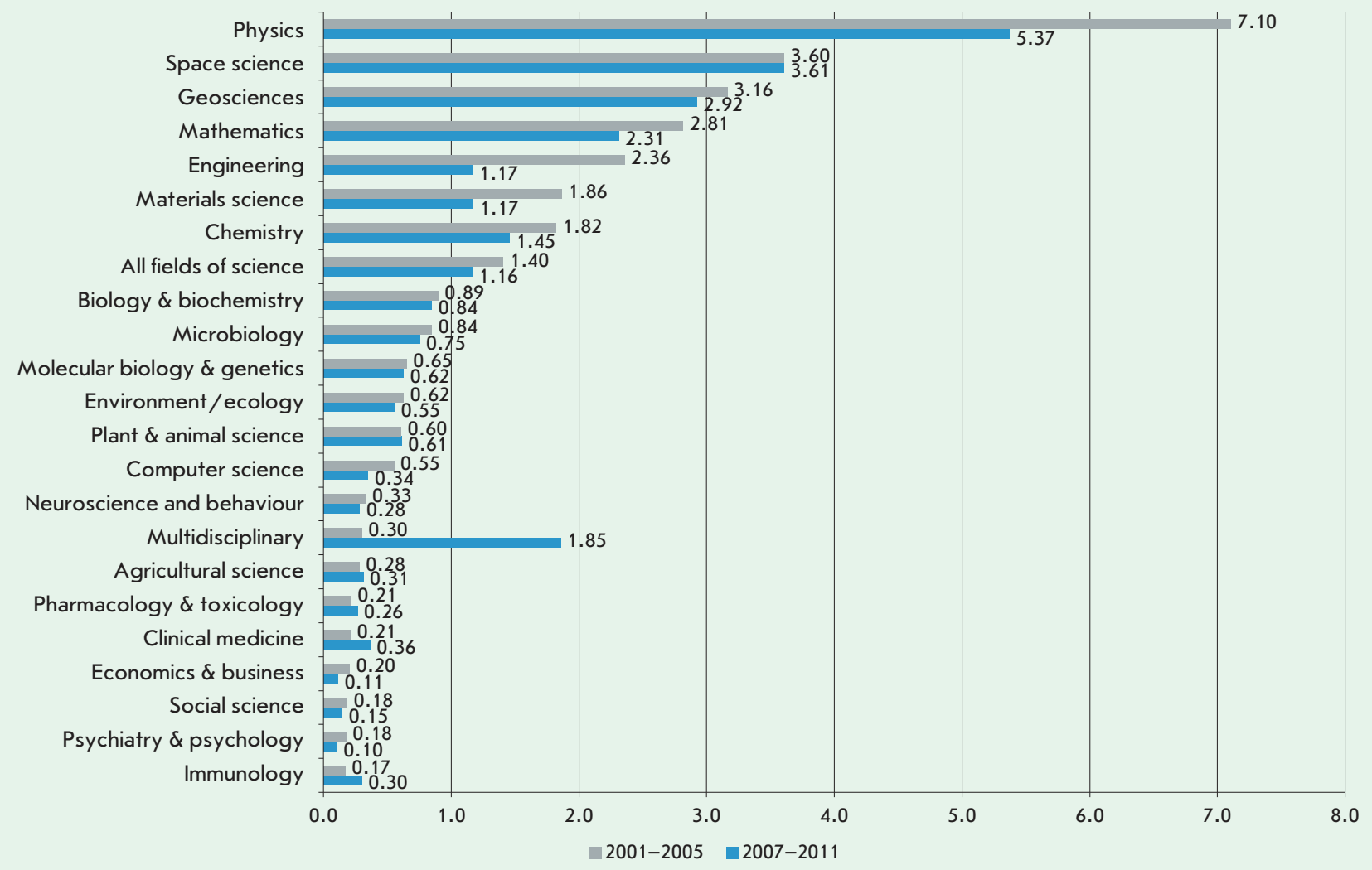

Fig. 3. Share of citations of Russian publications in the total world number of citations (\%).

Source: author calculations on Essential Science Indicators database materials (section "Citation Rankings, subsection "Countries/territories" country "Russia," option "View table of graph data" for indicators for Russia; section "Citation Analysis," subsection "Baselines," option "View field rankings table" for the total world indicators).

growth of the value if the ACP indicator over the studied period: from 0.39 in $2001-2005$ to 3.65 in 2007-2011. In 2007-2011, only the publications on multidisciplinary sciences had the level of the ACP indicator comparable to the world indicator. Russian publications on clinical medicine also showed relatively strong (by a factor of 2.28) increase of the ACP level over the studied period. In the world structure of science, publications on molecular biology \& genetics had the highest value of the ACP indicator.

\section{DYNAMICS OF HIGHLY- CITED PUBLICATIONS}

Highly-cited publications are a relatively small group of the most influential scientific publications. A publication in a certain field of science is considered to be highly cited if it is among the $1 \%$ of the most frequently cited publications in this field of science. Since the citation trends (frequency and time distribution of the citations) vary significantly in different fields of science, and the earlier published articles are cited more frequently than newly published ones, the distribution of citations over the years and individual fields of science are taken into account when determining the highly cited papers.

The highly-cited publications are frequently a result of international collaboration, which may bring together authors from different countries. Many of them form the so-called research fronts, the most topical and rapidly developing areas of research and developments in the world. The highly cited publications characterize the science system of a certain country to some extent $[11,12]$.

The index of scientific specialization for the highly-cited publications is calculated using the same procedure as for "usual" publications.

The dynamics of highly-cited Russian publications is shown in Fig. 4. Their distribution over the fields of science is listed in Table 10. After a significant reduction in 2009 , the number of highly cited papers in Russia increased to an even higher extent in 2010. 
Table 9. The average level of citations of Russian publications: distribution over fields of science: $2001-2011$

\begin{tabular}{|c|c|c|c|c|}
\hline \multirow[b]{2}{*}{ Field of science } & \multicolumn{2}{|c|}{$2001-2005$} & \multicolumn{2}{|c|}{$2007-2011$} \\
\hline & $\begin{array}{l}\text { Average number } \\
\text { of citations per } \\
\text { publication by } \\
\text { Russian authors }\end{array}$ & $\begin{array}{l}\text { The ratio between } \\
\text { the average } \\
\text { number of cita- } \\
\text { tions per publica- } \\
\text { tion by Russian } \\
\text { authors and the } \\
\text { world indicator }\end{array}$ & $\begin{array}{l}\text { Average number } \\
\text { of citations per } \\
\text { publication by } \\
\text { Russian authors }\end{array}$ & $\begin{array}{l}\text { The ratio between } \\
\text { the average } \\
\text { number of cita- } \\
\text { tions per publica- } \\
\text { tion by Russian } \\
\text { authors and the } \\
\text { world indicator }\end{array}$ \\
\hline Immunology & 4.6 & 0.48 & 7.21 & 0.73 \\
\hline Space science & 3.15 & 0.48 & 4.18 & 0.54 \\
\hline Biology \& biochemistry & 3.35 & 0.45 & 3.83 & 0.53 \\
\hline Clinical medicine & 1.62 & 0.31 & 3.69 & 0.64 \\
\hline Multidisciplinary & 0.39 & 0.23 & 3.65 & 1.04 \\
\hline Neuroscience \& behavior & 3.41 & 0.44 & 3.6 & 0.44 \\
\hline Molecular biology \& genetics & 3.42 & 0.29 & 3.58 & 0.33 \\
\hline Physics & 3.1 & 0.81 & 3.12 & 0.74 \\
\hline Microbiology & 2.52 & 0.37 & 3.03 & 0.44 \\
\hline Pharmacology \& toxicology & 3.35 & 0.68 & 2.71 & 0.47 \\
\hline Environmental science & 2.16 & 0.60 & 2.28 & 0.45 \\
\hline Geosciences & 1.39 & 0.42 & 1.93 & 0.44 \\
\hline Chemistry & 1.39 & 0.33 & 1.9 & 0.33 \\
\hline Plant \& animal science & 1.39 & 0.49 & 1.8 & 0.54 \\
\hline Materials science & 1.05 & 0.46 & 1.51 & 0.39 \\
\hline Engineering & 1.24 & 0.79 & 1.45 & 0.58 \\
\hline Agricultural science & 0.58 & 0.24 & 1.22 & 0.39 \\
\hline Economics \& business & 1.6 & 0.99 & 1.15 & 0.48 \\
\hline Psychiatry \& psychology & 1.01 & 0.28 & 1.13 & 0.24 \\
\hline Mathematics & 0.62 & 0.53 & 0.82 & 0.50 \\
\hline Computer science & 0.53 & 0.45 & 0.78 & 0.36 \\
\hline Social science & 0.35 & 0.22 & 0.67 & 0.33 \\
\hline All fields of sciences & 2.02 & 0.47 & 2.41 & 0.49 \\
\hline
\end{tabular}

Notes: All indicators calculated for the total number of publications indexed in the Web of Science database over the period of 2001-2011.

Source: author calculations on Essential Science Indicators database materials (section "Citation Rankings, subsection "Countries/territories" country "Russia," option "View table of graph data" for Russian indicators; section "Citation Analysis," subsection "Baselines", option "View field rankings table" for the total world indicators).

In the total world structure of highly-cited publications the following fields of science were the most important over the period of $2001-2011$ : clinical medicine $(22.0 \%)$, chemistry $(11.8 \%)$, physics $(8.7 \%)$, and engineering (8\%). The shares of Russian highly-cited publications from different fields of science in their total world number are given in Table 10). Russian highly-cited publications on physics accounted for almost half $(48.6 \%)$ of their total number. Clinical medicine, engineering, chemistry, and geosciences in sum accounted for another $28.6 \%$ of Russian highlycited publications in $2001-2011$.

Highly-cited publications on physics had the highest index of scientific specialization: Its share in the total number of the highly cited publications by Russian authors is more than fivefold higher than the identical world indicator. In Russia, the share of highly-cited publications on physics in the total number of highly cited papers is $\sim 48 \%$, whereas world indicator is $\sim 8.6 \%$. Hence, the index of scien- 


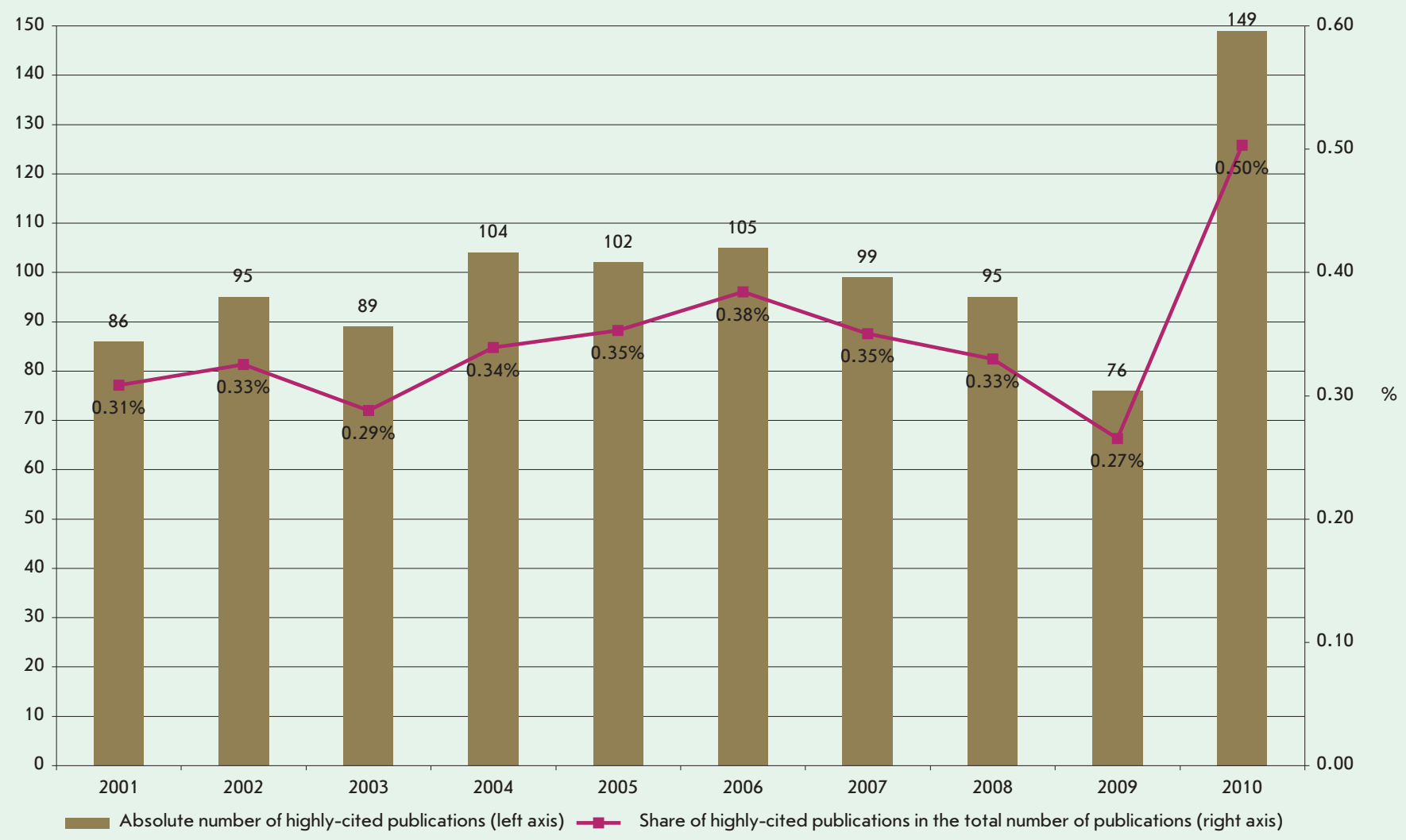

Fig. 4. Dynamics of the number of Russian highly-cited publications: 2001-2010.

Source: author calculations on Essential Science Indicators database materials (section "Most cited papers," subsection "Highly cited papers").

tific specialisation of Russian highly-cited publications on physics is $48 \% / 8.6 \%=5.6$. It is also should be noted that geosciences, space science, and mathematics were areas of specialisation of Russian highlycited publications. These highly-cited Russian publications contribute most substantially to world science. On the contrary, Russian publications in the field of immunology, pharmacology \& toxicology, neuroscience and behavior, psychiatry \& psychology, economics \& business, computer science, and social science prove the lowest potential of being highly cited.

Thus, the position of Russia in world science is strongest in the field of physics. Approximately half of highly-cited Russian publications and a significant share of the total number of Russian publications in scientific journals indexed by Web of Science are publications on physics.

Table 11 allows for analysis of positions of highly-cited Russian publications in the world (Table 11). As previously mentioned for the total number of publication the USA was the once again the stable global leader in terms of highly-cited publications, with $34.1 \%$ of their total world number. The second and third positions in the global ranking of the number of highly-cited publications were held by Great Britain (8.8\%) and Germany $(7.2 \%)$, respectively. China with the largest number of highly cited publications among the Asian countries held the sixth position in this ranking. Russia held the 21 st position with $0.64 \%$ of total world number of highly-cited publications.

Over the period of $2001-2011$, Switzerland had the highest share of highly cited publications in the total number of publications among the countries listed in Table 11 (2.3). On the contrary, in Russia this indicator was the lowest among the countries listed in Table $11(0.39 \%)$.

\section{INTERNATIONAL CO-AUTHORSHIP}

The last section of this work is a brief review of the major directions of international co-authorship by Russian authors (methods for evaluating the international co-authorship were discussed in [13-15]). The intensity and direction of international collaboration are typically measured using the analysis of co- authorship indicators for re- 
Table 10. Distribution of highly cited publications over fields of science: 2001-2011

\begin{tabular}{|c|c|c|c|c|}
\hline Field of science & World & Russia & $\begin{array}{l}\text { Share of Russian highly } \\
\text { cited publications in the } \\
\text { total number of highly } \\
\text { cited papers, } \%\end{array}$ & $\begin{array}{l}\text { Specialization index of } \\
\text { Russian publications }\end{array}$ \\
\hline Biology \& biochemistry & 5501 & 46 & 0.84 & 0.79 \\
\hline Immunology & 1252 & 2 & 0.16 & 0.15 \\
\hline Clinical medicine & 21783 & 104 & 0.48 & 0.45 \\
\hline Computer science & 2544 & 3 & 0.12 & 0.11 \\
\hline Mathematics & 2377 & 27 & 1.14 & 1.08 \\
\hline Materials science & 4572 & 27 & 0.59 & 0.56 \\
\hline Microbiology & 1646 & 6 & 0.36 & 0.35 \\
\hline Molecular biology \& genetics & 2806 & 18 & 0.64 & 0.61 \\
\hline Multidisciplinary & 180 & 4 & 2.22 & 2.11 \\
\hline Plant \& animal science & 2872 & 55 & 1.92 & 0.23 \\
\hline Geosciences & 1240 & 27 & 2.18 & 1.82 \\
\hline Space science & 5789 & 14 & 0.24 & 2.07 \\
\hline Environment/ecology & 2762 & 16 & 0.58 & 0.55 \\
\hline Neuroscience \& behavior & 3012 & 4 & 0.13 & 0.13 \\
\hline Social science & 4562 & 5 & 0.11 & 0.10 \\
\hline Psychiatry \& psychology & 2477 & 3 & 0.12 & 0.11 \\
\hline Agricultural science & 2041 & 3 & 0.15 & 0.14 \\
\hline Engineering & 7890 & 91 & 1.15 & 1.09 \\
\hline Pharmacology \& toxicology & 1848 & 4 & 0.22 & 0.21 \\
\hline Physics & 8600 & 508 & 5.91 & 5.61 \\
\hline Chemistry & 11699 & 77 & 0.66 & 0.62 \\
\hline Economics \& business & 1722 & 1 & 0.06 & 0.06 \\
\hline Total & 99175 & 1045 & 1.05 & \\
\hline
\end{tabular}

Notes: 1. All indicators were calculated for the total number of highly cited publications in the scientific journals indexed in the Web of Science database over the period of 2001-2011.

2. The data for December 2011 are listed in the table.

Source: author calculations on Essential Science Indicators database materials (section "Most cited papers," subsection "Highly cited papers").

searchers from different countries (e.g., $[1-5,14,16-18])$. Publication is considered to be written in international co-authorship if there are authors from at least two countries in the list of co-authors. In such publications, authorship is ascribed to all of the co-authors in an identical degree, irrespective of the share of contribution of the individual author to the paper. A high share of papers published in international co-authorship in the total number of publications of a country can be indicative both of its central position in the international research networks and of a lack of self-sufficiency within the framework of national science. In line with the changes in scientific production in the world, which assume the formation of larger research groups, a tendency towards hyper- and mega-authorship bringing together tens of authors from different countries has appeared in certain fields of science (the methods and methodology of assessing the "mul- tinationality" of publications written in international co-authorship were discussed in $[10,19,20])$.

The share of publications written in international co-authorship in the total number of publications is considered as a relative indicator of the level of integration of researchers of a particular country into the global scientific community. The basic indicators of the level of integration of Russian researchers into the global scientific community are shown in Fig. 5. The share of publications pre- 
Table 11. The main indicators of highly cited publications of the leading countries: 2001-2011

\begin{tabular}{|c|c|c|c|c|}
\hline Country & $\begin{array}{l}\text { Number of highly cited } \\
\text { publications }\end{array}$ & $\begin{array}{l}\text { Position in the ranking } \\
\text { of the number of highly } \\
\text { cited publications }\end{array}$ & $\begin{array}{c}\text { Share of highly cited } \\
\text { publications of the coun- } \\
\text { try in the total world } \\
\text { number of highly cited } \\
\text { publications, \% }\end{array}$ & $\begin{array}{c}\text { Share of highly cited } \\
\text { publications in the total } \\
\text { number of publications } \\
\text { of the country, } \%\end{array}$ \\
\hline USA & 55953 & 1 & 34.10 & 1.83 \\
\hline Great Britain & 14505 & 2 & 8.84 & 1.76 \\
\hline Germany & 12649 & 3 & 7.72 & 1.61 \\
\hline France & 7155 & 4 & 4.37 & 1.28 \\
\hline Canada & 6717 & 5 & 4.09 & 1.49 \\
\hline China & 5856 & 6 & 3.57 & 0.70 \\
\hline Japan & 5659 & 7 & 3.45 & 0.73 \\
\hline Italy & 5097 & 8 & 3.11 & 1.19 \\
\hline The Netherlands & 4808 & 9 & 2.93 & 1.91 \\
\hline Australia & 4210 & 10 & 2.57 & 1.38 \\
\hline Switzerland & 4171 & 11 & 2.55 & 2.30 \\
\hline Spain & 3584 & 12 & 2.18 & 1.06 \\
\hline Sweden & 2747 & 13 & 1.68 & 1.53 \\
\hline Belgium & 2310 & 14 & 1.41 & 1.68 \\
\hline Denmark & 1940 & 15 & 1.18 & 1.98 \\
\hline South Korea & 1773 & 16 & 1.08 & 0.63 \\
\hline Israel & 1450 & 17 & 0.88 & 1.31 \\
\hline Austria & 1438 & 18 & 0.87 & 1.50 \\
\hline India & 1238 & 19 & 0.76 & 0.42 \\
\hline Finland & 1172 & 20 & 0.72 & 1.32 \\
\hline Russia & 1045 & 21 & 0.63 & 0.39 \\
\hline
\end{tabular}

Notes: 1. All indicators were calculated for the total number of highly cited publications in the scientific journals indexed in the Web of Science over the period of 2001-2011.

2. The 2011 data correspond to the situation by the beginning of data for December 2011 is listed in the table. Source: author calculations on Essential Science Indicators database materials (section "Most cited papers," subsection "Highly cited papers").

pared in international co-authorship in the total number of Russian publications over the period of $2001-2011$ fluctuated around $29 \%-33 \%$. It corresponded to the absolute number of approximately 9,000 publications. However, a decrease in the number of publications prepared in international co-authorship started in 2008.

Researchers from the USA and Germany were the main foreign partners of Russian researchers (Table 12): $26 \%-27 \%$ of the total number of Russian publications in international collaboration was prepared in co-authorship with researches from these countries. French and British researchers were also significant partners of Russian scientists. The strengthening of scientific links between Russia and Asian countries should also be noted. The number of publications by Russian authors in co-authorship with their Indian, Chinese and Taiwanese, and South Korean colleagues increased by a factor of 3.6; 3.1, and 4.6, respectively, over the period of 2001-2011. The development of scientific cooperation between Russia and European countries was less dynamic. Among the former USSR countries, only Ukraine and Belarus were included in the cohort of the 25 most significant scientific partners of Russia.

On the other hand, Russia was an important scientific partner for Central Asian and Caucasian countries, as well as for Mongolia, Ecuador, Ukraine, and Belarus ( $\mathrm{Ta}$ ble 13). Meanwhile, Russia was an insignificant scientific partner for such countries as the USA, Germany, France, and Great Britain. For these countries the share of publications prepared in co-authorship with Russia, in the total number 


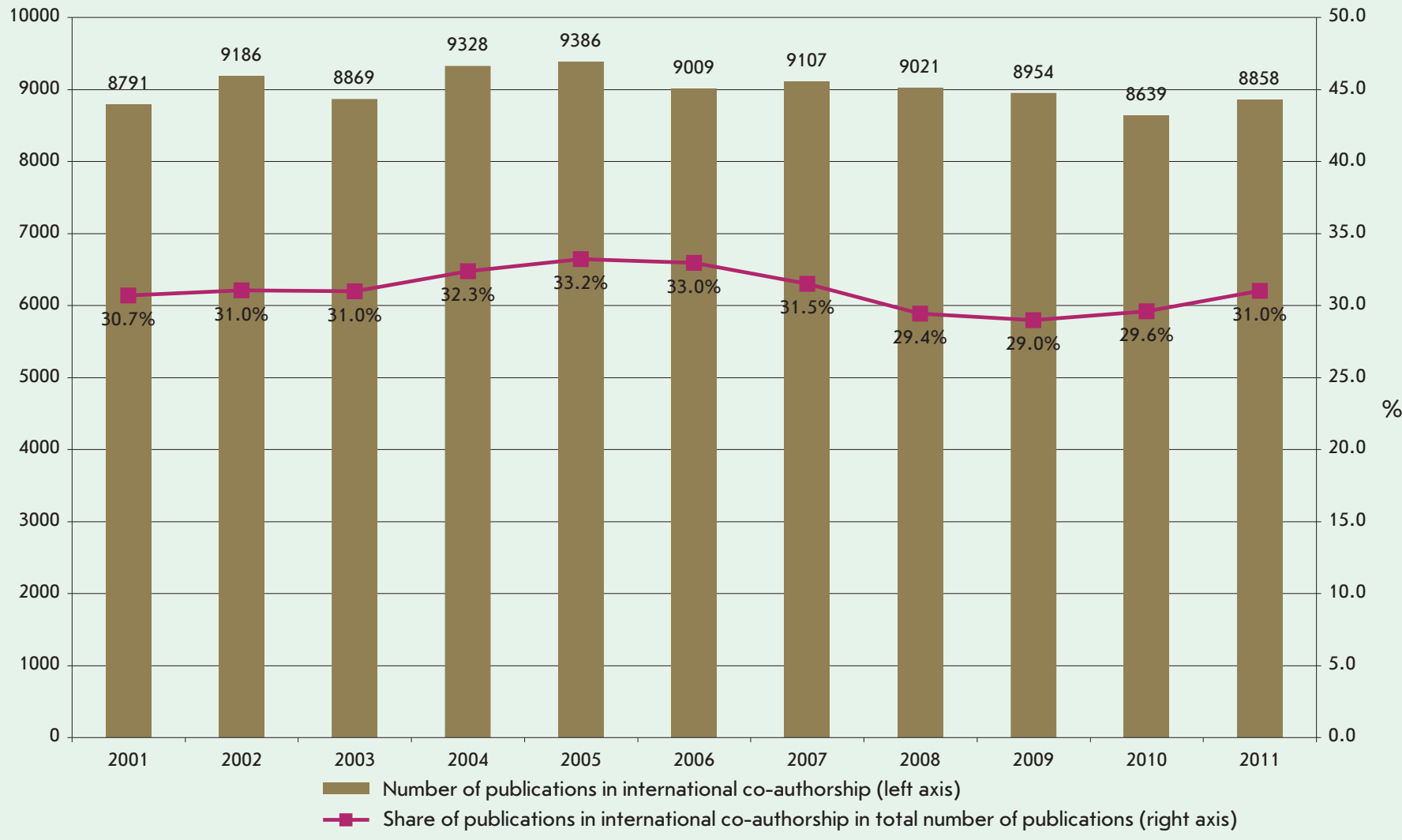

Fig. 5. Basic indicators of international collaboration by Russian authors: 2001-2011.

The number of publications of Russian authors prepared in international co-authorship was calculated using the following procedure: the publications were tallied for each year over the studied period and all countries, except for Russia, using the option "Analyze results" of the Web of Science database for the country "Russia" in the category "Countries/territories."

of publications in co-authorship amounted to less than $3.5 \%$.

In Northern European countries, the level of integration of researchers of these countries into the global scientific community was considerably higher than in Russia (approximately 50\%). This indicator was even higher in Indonesia, Cyprus, Tajikistan, Turkmenistan, Kyrgyzstan, and Uzbekistan: $60-65 \%$ in recent years [21-23]. This indicator was also high for countries with transition economies (e.g., Latvia, Estonia, and Belarus). The indicator has always been high for such countries as Germany, France, and Canada: almost half of all publications made in these countries were the result of international collaboration. On the contrary, among the top 30 countries in number of publications, this indicator is the lowest for China, India, Turkey, and Iran. In general, the level of integration of researchers into the global scientific community in European countries was higher than the level observed in Asian countries.

Bibliometric analysis of the patterns of academic co-authorship at the world level have shown a significant increase in the number of publications prepared in international collaboration during the past 20-30 years. This phenomenon can interpreted as the sign of the deepening of specialization and globali- zation of knowledge production. In particular, the increasing role of the BRIC countries in international collaboration has been noted; with Russia as a leader on this indicator among the four BRIC countries. The number of Russian publication in Web of Science database prepared in international co-authorship over the period from 1980 to 2011 jumped from $3 \%$ to $31 \%$, reaching parity with the level achieved by the USA.

The distribution of Russian publications in international co-authorship over various fields of science generally corresponds to the areas of the scientific specialization of Russia: physics holds a signifi- 
Table 12. The main scientific partners of Russia

\begin{tabular}{|c|c|c|c|c|c|c|}
\hline \multirow[b]{2}{*}{ № } & \multicolumn{3}{|c|}{2001} & \multicolumn{3}{|c|}{2011} \\
\hline & Country & $\begin{array}{l}\text { Number of } \\
\text { publications in } \\
\text { co-authorship }\end{array}$ & $\begin{array}{l}\text { Share of pub- } \\
\text { lications in the } \\
\text { total number } \\
\text { of Russian } \\
\text { publications in } \\
\text { international co- } \\
\text { authorship, \% }\end{array}$ & Country & $\begin{array}{l}\text { Number of } \\
\text { publications in } \\
\text { co-authorship }\end{array}$ & $\begin{array}{l}\text { Share of pub- } \\
\text { lications in the } \\
\text { total number } \\
\text { of Russian } \\
\text { publications in } \\
\text { international co- } \\
\text { authorship, \% }\end{array}$ \\
\hline 1 & Germany & 2389 & 27.18 & Germany & 2564 & 28.95 \\
\hline 2 & USA & 2158 & 24.55 & USA & 2366 & 26.71 \\
\hline 3 & France & 1076 & 12.24 & France & 1499 & 16.92 \\
\hline 4 & Great Britain & 902 & 10.26 & Great Britain & 1390 & 15.69 \\
\hline 5 & Japan & 681 & 7.75 & Italy & 924 & 10.43 \\
\hline 6 & Italy & 651 & 7.41 & Spain & 730 & 8.24 \\
\hline 7 & Sweden & 493 & 5.61 & Japan & 665 & 7.51 \\
\hline 8 & The Netherlands & 432 & 4.91 & China & 635 & 7.17 \\
\hline 9 & Poland & 423 & 4.81 & Poland & 621 & 7.01 \\
\hline 10 & Switzerland & 346 & 3.94 & Switzerland & 582 & 6.57 \\
\hline 11 & Canada & 319 & 3.63 & Ukraine & 540 & 6.10 \\
\hline 12 & Ukraine & 318 & 3.62 & Canada & 514 & 5.80 \\
\hline 13 & Spain & 315 & 3.58 & Sweden & 508 & 5.73 \\
\hline 14 & Finland & 260 & 2.96 & The Netherlands & 494 & 5.58 \\
\hline 15 & Belgium & 246 & 2.80 & Finland & 490 & 5.53 \\
\hline 16 & South Korea & 220 & 2.50 & Czech Republic & 457 & 5.16 \\
\hline 17 & Czech Republic & 216 & 2.46 & Belgium & 425 & 4.80 \\
\hline 18 & China & 202 & 2.30 & Austria & 405 & 4.57 \\
\hline 19 & Israel & 185 & 2.10 & South Korea & 398 & 4.49 \\
\hline 20 & Austria & 151 & 1.72 & Brazil & 361 & 4.08 \\
\hline 21 & Brazil & 150 & 1.71 & India & 331 & 3.74 \\
\hline 22 & Denmark & 150 & 1.71 & Taiwan & 310 & 3.50 \\
\hline 23 & Mexico & 149 & 1.69 & Belarus & 299 & 3.38 \\
\hline 24 & Norway & 147 & 1.67 & Australia & 299 & 3.38 \\
\hline 25 & Australia & 140 & 1.59 & Greece & 288 & 3.25 \\
\hline
\end{tabular}

Notes: 1 . The total of the shares for the countries is higher than $100 \%$, since some papers were prepared in co-authorship with researchers from more than one country.

2. The procedure for calculating the total number of publications by Russian authors in international co-authorship is described in the legend to Fig. 5.

Source: author calculations on Web of Science database materials.

cant lead (in particular, solid body physics and sub-disciplines studying nuclear processes, fields and particles; optics and spectroscopy, and plasma physics). Astronomy \& astrophysics, material science, physical chemistry, instrument engineering, biochemistry \& mo- lecular biology, geosciences, mathematics, and electronics follow these disciplines..

\section{CONCLUSIONS}

The publication activity of Russian scientists and the research efficiency of the leading scientific countries were reviewed. The dynamics of the number of publications in scientific journals indexed in the Web of Science database and the basic citation indicators was analysed for the countries of studied sample (countries with more than 10000 publications in scientific journal, indexed 
Table 13. Share of publications in co-authorship with Russian researchers in the total number of publications of the country: 2001-2011 (\%)

\begin{tabular}{|l|l|l|l|}
\hline \multicolumn{1}{|c|}{ Country } & 2001 & \multicolumn{1}{c|}{ Country } & 2011 \\
\hline Turkmenistan & 40.00 & Georgia & 30.94 \\
\hline Tajikistan & 24.00 & Belarus & 27.66 \\
\hline Armenia & 19.83 & Armenia & 26.29 \\
\hline Kazakhstan & 17.87 & Kyrgyzstan & 23.44 \\
\hline Georgia & 17.56 & Kazakhstan & 23.18 \\
\hline Ecuador & 16.35 & Mongolia & 19.29 \\
\hline Uzbekistan & 13.02 & Azerbaijan & 18.04 \\
\hline Mongolia & 12.50 & Uzbekistan & 15.45 \\
\hline Belarus & 8.48 & Tajikistan & 14.81 \\
\hline Ukraine & 6.40 & Ecuador & 13.61 \\
\hline Azerbaijan & 5.44 & Ukraine & 10.34 \\
\hline
\end{tabular}

Notes: 1. The indicators listed in the table are calculated as follows: for each country, the number of publications in co-authorship with Russian researchers is the indicator "Record count" in the box "Russia," which is shown after the function "Search within results for Countries/territories" in the option "Analyze results" in the Web of Science database is executed. The following types of documents were selected for the analysis: article, proceedings paper, and review.

2. The countries whose share of publications in co-authorship with Russian researchers in the total number of publications of the country was higher than $10 \%$ in 2001 or 2011 are listed.

Source: author calculations on Web of Science database materials. All databases of the Web of Science portal were used.

by Web of Science over the period of $2001-2011$ ). The fields of scientific specialization for Russia were also identified. Moreover, the analysis has demonstrated that Russia lost positions in the world science over the period from 2001 to 2011. Countries with dynamic publication activity rose to overtake Russia in the world rating. The most significant loss of position for Russia occurred in the fields that are considered of traditional strength for Russia (physics, engineering, materials science, chemistry and mathematics). Furthermore, the average number of citations per paper in Russia was one of the lowest in the world.

The conclusions concerning the scientific specialization of Russia can be drawn through analysis of other fields of science) to the total number of Russian publications in international co-authorship.

The level of integration of Russian researchers into the world scientific community was relatively high. However, this indicator was higher in European countries (in particular, in Northern European countries). The main scientific partners of Russian researchers were scientists from the USA, Germany, Great Britain, and France. Scientific cooperation between Russian scientists and their colleagues from Asian countries (primarily from China, India and South Korea) considerably strengthened over the period of $2001-2011$.

The following conclusions can be drawn from the analysis of the publication activity in the other countries. In 2001-2011, the U.S. clearly held the leading positions in the world science. The publication activity in Asian countries was much more dynamic than in European countries. Iran demonstrated the highest growth rate of the indicators of publication activity among the countries of the studied sample. However, the citation indicators and the level of international scientific collaboration were in European countries were higher than in Asian countries. Therefore, a significant rearrangement in world science has occurred over the past 10 years. Developing countries (primarily China, and also Iran, Thailand, Turkey, Malaysia, Brazil, Pakistan, and India) have begun closing the gap with the established leaders (North American countries, Northern European countries, and Japan). Because of the strengthening in this trend, Russia's lagging will manifest itself largely. By the next decade Russia may lose its status as one of the world's great scientific countries without timely reforms in scientific policy. 
REFERENCES

1. Gokhberg L.M. Statistika nauki (Statistics of Science). Moscow: TEIS, 2003. 478 p.

2. Gokhberg L.M., Sagieva G.S. // Forsait (Foresight). 2007.

V. 1. № 1. P. $44-53$.

3. Kirchik O.I. // Forsait (Foresight). 2011. V. 5. № 3. p. 34-42.

4. Rossijskij innovacionnyj indeks (Russian Innovation Index) / Ed. L. M. Gokhberg. Moscow: Higher School of Economics, 2011. 84 p.

5. Kotsemir M.N. // Forsait (Foresight). V. 6. №.1.

6. Merton R.K. // Science. 1968. V. 159. Iss. 3810. P. 56-63.

7. Merton R.K. // ISIS. 1998. V. 79. № 4. P. 606-623.

8. Gokhberg L., Pislyakov V. // 10th International Conference on Science and Technology Indicators. Book of Abstracts. 2008. Vienna. P. 400-403.

9. Batygin G.S. // Vedomosti. Tyumen Oil and Gas University, Institute for Applied Ethics. 2001. Iss. 18. P. 173-185.

10. Pislyakov V.V. // Preprint WP6/2010/01. 2010. Moscow. Higher School of Economics.

11. Aksnes D.W., Sivertsen G. // Scientometrics. 2004. V. 59. № 2. P. 213-224.

12. Tijssen R.J.W., Visser M.S., Van Leeuwen T.N. // Scientometrics. 2002. V. 54. P. 381-397.

13. Luukkonen T., Tijssen, R.J.W., Persson O., Silvertsen G //
Scientometrics. 1993. V. 28. P. 15-36.

14. Glänzel W., Schubert A., Czerwon H.J. // Scientometrics. 1999. V. 45. P. $185-202$.

15. Bookstein A., Moed H., Yitzhaki M. // Information

Processing and Management. 2006. V. 42. P. 1422-1442.

16. Melin G., Persson O. // Scientometrics. 1996. V. 36.

P. 363-377.

17. Arunachalam S., Doss M.J. // Current Science. 2000. V. 79. № 5 .

18. Wang Y., Wu Y., Pan Y., Ma Z., Rousseau R. // Scientometrics. 2005. V. 62. № 2. P. 183 - 198.

19. Lange C., Glänzel W. // Scientometrics. 1997. V. 49. № 3. P. 593-604.

20. Nederhof A.J., Moed H.F. // Scientometrics. 1993. V. 27. P. $39-52$.

21. Indikatory nauki: 2010. Statisticheskij sbornik (Indicators of Science 2010: Statistics Digest). Moscow: HSE, 2010. $368 \mathrm{p}$.

22. Indikatory nauki: 2011. Statisticheskij sbornik (Indicators of Science 2011: Statistics Digest). Moscow: HSE, 2011. $368 \mathrm{p}$.

23. Indikatory nauki: 2012. Statisticheskij sbornik (Indicators of Science 2012: Statistics Digest). Moscow: HSE, 2012. $392 \mathrm{p}$. 